\title{
兴蒙地区二叠系乐平统林西组上部发现海相化石
}

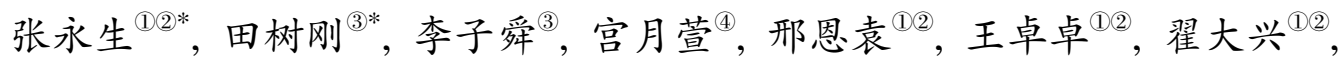
曹洁 $^{(12)}$, 苏奎 ${ }^{(12)}$, 王猛 ${ }^{(1) 2}$

(1) 中国地质科学院矿产资源研究所, 北京 100037 ;

(2) 国土资源部盐湖资源与环境重点实验室，北京 100037;

(3) 中国地质科学院地质研究所, 北京 100037 ;

(4) 中国地质科学院, 北京 100037

*联系人, E-mail: zys_601@126.com; sgtian@cags.ac.cn

2013-04-03 收稿, 2013-08-20 接受, 2013-11-05 网络版发表

中国地质调查项目(1212011120972)和国家自然科学基金(41072021)资助

摘要 华北板块、西伯利亚板块和中间地块在兴蒙地区的最终闭合、兴蒙海槽褶皱隆起的时代 是地质界长期争论的重大地质问题，争论的焦点是以林西组为代表的晚二叠世构造-古地理环 境. 目前, 绝大部分学者认为兴蒙地区晚二叠世为陆相沉积, 少数学者认为晚二叠世早-中期为 封闭内海盆地, 晚期转变为陆相淡水湖盆沉积. 本研究在内蒙古东部林西县官地-翟家沟剖面 林西组上部的厚层灰岩和灰岩透镜体中首次发现大量苔藓虫和海绵骨针等典型海相化石. 此 外, 在阿鲁科尔沁旗陶海营子剖面陶海营子组上部沉凝灰岩切片中发现大量苔藓虫化石, 在吉 林省九台市杨家沟剖面杨家沟组暗色页岩中发现大量小型连体海百合茎化石。上述官地-翟家 沟剖面林西组上部多层灰岩中大量苔藓虫和海绵骨针以及邻区相当层位中苔藓虫、海百合茎等 典型海相化石的发现, 确认兴蒙地区在晚二叠世晚期仍属海相或以海相为主的沉积环境, 对厘 定兴蒙海盆的最终闭合提供了新的证据, 并将促进东北-兴蒙地区晚二叠世新层系油气、页岩气 (油)以及其他矿产勘查研究思路的调整.

关键词

二叠系

乐平统

林西组上部

海相化石

兴蒙地区
以林西组为代表的兴蒙地区 (内蒙古东部及邻区) 晚二叠世沉积的构造-古地理环境一直是人们研究的 热点. 林西组命名于林西县官地-翟家沟剖面, 顾国 寅和胡泽瑾 ${ }^{[1]}$ 将该剖面划分为 4 段( $\left.\mathrm{A} \sim \mathrm{D}\right)$, 其中 $\mathrm{A} \sim \mathrm{B}$ 段为林西组, $C \sim D$ 段为陶海营子组, 分别构成独立的 沉积旋回; 梁仲发 ${ }^{[2]}$ 根据双壳类化石确定林西组属晚 二叠世; 内蒙古区域地质志 ${ }^{[3]}$ 描述的该剖面厚度不小 于 $3170 \mathrm{~m}$, 相当于顾国寅等的 $\mathrm{A} \sim \mathrm{C}$ 段; 张永生等人 ${ }^{[4]}$ 在林西组上部实测剖面第 70 小层发现的林西黄河叶 肢介(新种)等化石是华北地台晚二叠世的特有类型， 结合同层位产出的古米台蚌-古无齿蚌双壳类化石组 合, 确定林西组的地层时代为晚二叠世. 本次研究
对林西县官地-翟家沟剖面进行了进一步修测(图 1), 总厚度 $4933.64 \mathrm{~m}$, 将林西组自下而上划分为林一段 至林五段共 5 个岩性段(图 2), 系统采集了各类化石 样品, 在该剖面林西组上部的林四段-林五段(第 71 75 小层)厚层灰岩和灰岩透镜体中发现大量苔藓 虫和海绵骨针等典型海相化石，首次确认兴蒙地区 在晚二叠世晚期仍属海相或以海相为主的沉积环境.

\section{1 剖面描述}

林西组剖面位于林西县官地镇大井村-翟家沟, 起点坐标： $43^{\circ} 41^{\prime} 42^{\prime \prime} \mathrm{N}, 118^{\circ} 15^{\prime} 11^{\prime \prime} \mathrm{E}$, 终点坐标: $43^{\circ} 45^{\prime} 07^{\prime \prime} \mathrm{N}, 118^{\circ} 05^{\prime} 23^{\prime \prime} \mathrm{E}$.

引用格式: 张永生, 田树刚, 李子舜, 等. 兴蒙地区二叠系乐平统林西组上部发现海相化石. 科学通报, 2013, 58: 3429-3439 Zhang Y S, Tian S G, Li Z X, et al. Discovery of marine fossils in the upper part of the Permaian Linxi Formation in Lopingian, Xingmeng area, China (in Chinese). Chin Sci Bull (Chin Ver), 2013, 58: 3429-3439, doi: 10.1360/972013-398 


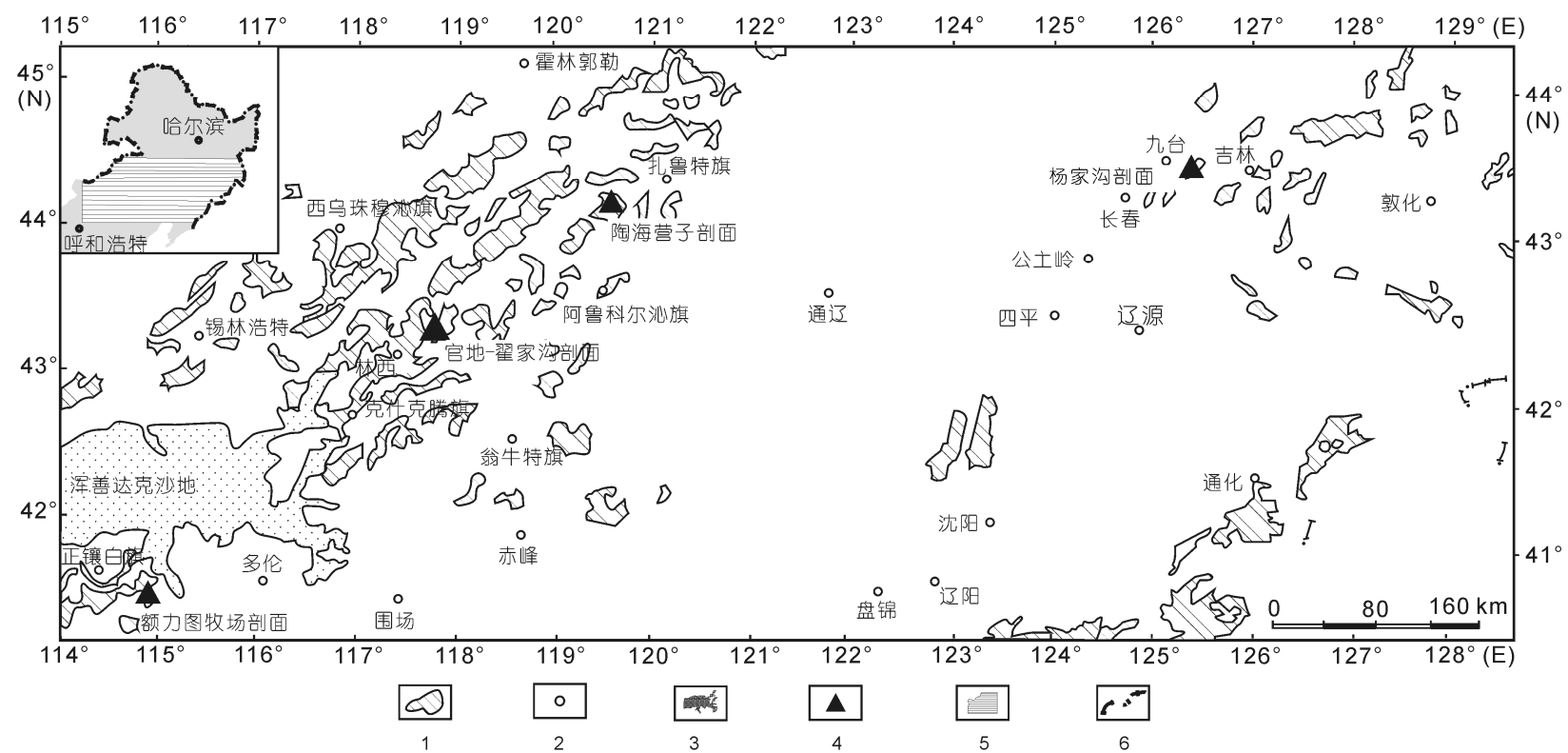

图 1 兴蒙地区二叠系分布略图及主要剖面位置

1 , 二叠系露头; 2 , 地名; 3 , 浑善达克沙地; 4 , 剖面位置; 5 , 研究区; 6 , 国境线

将林西官地剖面林西组划分为 5 个岩段，自下而 上为林西组一段(简称“林一段”)至林西组五段(简称 “林五段”)，现分述如下：

上二叠统 林西组: 厚度 $4933.64 \mathrm{~m}$

\section{林五段}

厚 $327.52 \mathrm{~m}$

未见顶(海西期花岗岩侵人)

76. 灰白色中厚层凝灰质粉细砂岩, 夹灰褐色、粉红色厚层 灰岩和灰绿色砂屑凝灰岩

$188.61 \mathrm{~m}$

75. 灰褐色厚层块状灰岩、灰白色中厚层凝灰质粉细砂岩和 粉砂岩, 夹粉红色安山岩. 厚层块状灰岩中含大量苔藓 虫和海绵骨针化石(图 3(B): (b) (i)) $77.78 \mathrm{~m}$

74. 灰绿色、灰白色薄-中层中细粒硬砂岩、泥质粉砂岩和粉 砂质泥岩

$61.13 \mathrm{~m}$

\section{林四段}

厚 $501.07 \mathrm{~m}$

73. 黑色、灰黑色粉砂质泥岩、泥质粉砂岩，夹黑色页岩、 薄层和透镜状藻叠层和藻团块灰岩和灰绿色、灰色薄中 层细粒长石石英砂岩 $150.08 \mathrm{~m}$

72. 黑色、灰黑色粉砂质泥岩、泥质粉砂岩, 夹炭质页岩、 薄层灰岩和灰岩透镜体. 薄层灰岩和灰岩透镜体中含大 量苔藓虫化石(图 3(A): (a) (d); 图 3(B): (a)) 105.49 m

71. 下部为深灰色、灰绿色薄中层细粒长石砂岩, 夹黑色泥 质粉砂岩; 中-上部为深灰色、黑色板状粉砂泥岩, 夹灰 色板状泥质粉砂岩. 含双壳类化石: Palaeomutella soronensis, P. cf. trigonalis, Palaeanodonta sp.; 含植物化 石: Paracalamites sp. Noeggerathiopsis sp. $\quad 152.05 \mathrm{~m}$ 70. 灰黑色、黑色粉砂质泥岩, 泥质粉砂岩、黑色页岩, 夹
深灰色中层状细粒长石砂岩. 泥岩中含大量叶肢介化石: Huanghestheria linxiensis $\mathrm{Niu}(\mathrm{sp}$. nov.), Cyclotunguzites cf. gazimuri Novojilov, Sphaerorthothemos cf. cellulatus(Lutkevich)

$93.45 \mathrm{~m}$

林三段

厚 $1791.72 \mathrm{~m}$

69. 灰绿色、深灰色薄板状粉砂泥岩、泥质粉砂岩和黑色泥 岩, 夹深灰色中层状细粒长石砂岩

$232.23 \mathrm{~m}$

68. 灰色、灰绿色泥质胶结中厚层细粒砂岩, 夹深灰色板片 状泥质粉砂岩，见有少量灰岩透镜体，底部为灰色、灰 绿色中厚层状泥质胶结粉细砂岩

$72.92 \mathrm{~m}$

67. 深灰色板片状结构的粉砂质泥岩和泥质粉砂岩, 夹灰绿 色泥质胶结粉细砂岩

$244.12 \mathrm{~m}$

66. 灰色、深灰色中厚层状细粒长石石英砂岩, 夹深灰色板 片状泥质粉砂岩

$88.29 \mathrm{~m}$

65. 灰色、深灰色薄板状泥质粉砂岩, 夹灰色中层状细粒长 石石英砂岩

$172.23 \mathrm{~m}$

64. 灰色、灰绿色中厚层细粒长石砂岩, 夹灰色、深灰色泥 质粉砂岩

$33.22 \mathrm{~m}$

63. 灰色、深灰色薄板状粉砂质泥岩、页岩 $34.69 \mathrm{~m}$

62. 灰色、灰绿色中厚层状细粒石英长石砂岩, 夹灰色薄板 状泥质粉砂岩 $47.57 \mathrm{~m}$

61. 灰绿、灰色薄板状泥质粉细砂岩, 夹薄中层状长石石英 砂岩和细粒长石砂岩

$41.55 \mathrm{~m}$

60. 灰色、灰绿色薄板状泥质粉砂岩, 夹中层状粉细砂岩 $32.65 \mathrm{~m}$

59. 灰黑色薄板状粉砂质泥岩和钲质泥岩. 含双壳类化石: Palaeomutella klinganensis, $P$. soronensis, $P$. hahaiensi, $P$. cf. subparallela, $P$. subrectangularis, $P$. cf. semilunulata, $P$. lunulata, $P$. cf. lunulata
$13.47 \mathrm{~m}$ 
58. 灰绿色板状泥质粉细砂岩, 岩内见黄铁矿 $44.02 \mathrm{~m}$

57. 灰色、深灰色中厚层细粒石英长石砂岩, 砂岩内见许多 黑色斑点

$10.45 \mathrm{~m}$

56. 深灰色、灰黑色板状粉砂质泥岩和钙质泥岩, 夹灰色、 灰绿色薄中层中细粒长石砂岩

$42.99 \mathrm{~m}$

55. 灰色、深灰色薄中层中细粒长石砂岩与灰黑色、黑色板 状粉砂泥岩和粉砂岩互层. 含植物化石碎片: Calamites sp., Paracalamites sp., Noeggerathiopsis sp., N. cf. Derzavinii $97.57 \mathrm{~m}$

54. 黑色、灰黑色板状粉砂泥岩和黑色页岩, 夹泥质粉砂岩 $106.35 \mathrm{~m}$

53. 灰色、灰绿色、灰黑色薄层钙质泥岩, 夹中厚层中细粒 长石砂岩、板状泥质粉砂岩和粉砂泥岩

$51.80 \mathrm{~m}$

52. 黑色、深灰色、灰黑色薄板状粉砂泥岩和泥岩, 夹页岩 和细砂岩透镜体

$68.87 \mathrm{~m}$

51. 灰色、灰绿色薄层板状泥质胶结的粉细长石砂岩, 与灰 色、灰黑色板状粉砂质泥岩互层 $203.75 \mathrm{~m}$

50. 灰色、灰绿色板状粉砂质泥岩, 夹灰黑色页岩 $51.35 \mathrm{~m}$

49. 深灰色、灰黑色薄层板状粉砂泥岩和板状泥岩, 夹 2 层 灰绿色中厚层状细粒石英长石砂岩

$69.26 \mathrm{~m}$

48. 灰色、灰绿色薄中层状含细砾石英长石石英, 夹灰黑色 板状泥岩和薄层泥灰岩

$32.37 \mathrm{~m}$

$$
\text { 林二段 }
$$

厚 $1080.52 \mathrm{~m}$

47. 黑色、灰黑色泥质页岩和粉砂质页岩, 夹灰色薄中层长 石砂岩

$88.64 \mathrm{~m}$

46. 灰色、灰绿色薄中层细粒长石砂岩, 夹薄层板状细粒长 石砂岩和泥质粉砂岩

$46.92 \mathrm{~m}$

45. 灰色、深灰色钙质页岩, 下部为深灰色厚层块状安山岩 $51.85 \mathrm{~m}$

44. 深灰色、灰黑色薄层板状泥质粉砂岩, 夹薄中层状细粒 长石砂岩, 砂岩中层面密布波痕

$73.04 \mathrm{~m}$

43. 黑色泥质页岩和粉砂页岩, 夹安山玢岩 $108.32 \mathrm{~m}$

42. 灰色、深灰色薄层板状富白云母泥质粉砂岩, 夹黑色粉 砂质页岩和灰白色中厚层状细粒长石砂岩透镜体

$15.09 \mathrm{~m}$

41. 黑色、灰黑色泥质页岩和粉砂页岩, 夹灰绿色薄中层状 细粒长石砂岩透镜体

$71.59 \mathrm{~m}$

40. 灰色、深灰色薄层板状附白云母泥质粉砂岩, 夹黑色粉 砂质页岩和灰白色中厚层状细粒长石砂岩透镜体

$52.80 \mathrm{~m}$

39. 灰色薄中层细粒长石砂岩, 与深灰色薄层板状泥质粉砂 岩互层, 夹灰黑色页岩

$33.22 \mathrm{~m}$

38. 灰色、深灰色薄层板状附白云母泥质粉砂岩, 夹黑色粉 砂质页岩和灰白色中厚层状细粒长石砂岩透镜体

37. 灰黑色、黑色钙质页岩

$127.14 \mathrm{~m}$ $47.10 \mathrm{~m}$

36. 灰色、深灰色薄层板状泥质粉砂岩, 与黑色页岩互层 $38.26 \mathrm{~m}$

35. 黑色钙质、炭质页岩, 夹灰色、灰绿色中厚层状中细粒 长石石英砂岩透镜体

$34.98 \mathrm{~m}$
34. 灰黑色薄中层状钙质粉砂岩, 夹灰绿色中厚层细粒长石 石英砂岩 $27.26 \mathrm{~m}$

33. 灰色、灰绿色薄中层泥质石英长石砂岩, 夹灰色粉砂质 页岩

$53.34 \mathrm{~m}$

32. 黑色、灰黑色薄层板状泥质粉砂岩、钙质泥岩, 夹灰绿 色中厚层砂岩透镜体

$59.42 \mathrm{~m}$

31. 土黄色薄中厚层状中细粒长石砂岩 $9.38 \mathrm{~m}$

30. 黑色、灰黑色页岩、粉砂质页岩和钙质泥岩, 夹灰绿色 中厚层细粒杂砂岩

$51.09 \mathrm{~m}$

29. 黑色、灰黑色中层钙质粉砂岩、泥岩, 夹黑色页岩和灰 色中厚层细粒杂砂岩

$91.08 \mathrm{~m}$

$$
\text { 林一段 }
$$

厚 $1232.81 \mathrm{~m}$

28. 灰色、深灰色薄中层状细粒杂砂岩, 砂岩风化面呈薄 板状, 砂岩内见有黑色闪石、长石和石英, 并含有大量 炭屑

$30.10 \mathrm{~m}$

27. 黑色、深灰色粉砂泥岩和钙质泥岩, 夹黑色页岩

$25.23 \mathrm{~m}$

26. 土黄色、灰绿色中厚层中粗粒长石石英砂岩, 夹灰绿色 纹层状钙质粉砂岩和粉砂泥岩

$45.27 \mathrm{~m}$

25. 土黄色、灰绿色、灰色中厚层状中粗粒长石石英砂岩

$23.92 \mathrm{~m}$

24. 深灰色粉砂质泥岩、钙质泥岩、与灰绿色、土黄色中厚 层细粒长石石英砂岩互层

$3.66 \mathrm{~m}$

23. 粉黄、粉红、灰褐色、灰绿色中厚层细粒长石砂岩

$77.24 \mathrm{~m}$

22. 灰色、灰绿色中厚层细粒长石石英砂岩和砂屑灰岩、钻 质粉砂岩、粉砂泥岩的交互层

$50.52 \mathrm{~m}$

21. 黑色、灰黑色碳质泥岩、钙质泥岩夹黑色薄层泥灰岩和 灰绿色砂岩夹灰岩透镜体, 夹薄中层泥晶灰岩

$46.15 \mathrm{~m}$

20. 灰色、灰绿色薄层中、中厚层状细粒长石砂岩, 夹深灰 色粉砂泥岩

$17.57 \mathrm{~m}$

19. 灰黑色钙质泥岩, 夹薄层板状泥灰岩

$29.59 \mathrm{~m}$

18. 灰色、深灰色中厚层状钙质粉砂岩与灰黑色粉砂质泥岩 和钙质泥岩互层, 夹灰色中厚层泥晶灰岩和泥灰岩透镜 体，层内粉砂岩顶见有波痕，泥岩中见大量双壳类化石： Palaeanodonta sp., Palaeomutella sp., Anthraconaia sp. 灰岩中见有叠层藻席构造和泄水脉

$16.86 \mathrm{~m}$

17. 灰色、灰绿色粉砂质泥岩, 夹灰绿色中层状泥质粉砂岩 和泥质粉细砂岩

$14.33 \mathrm{~m}$

16. 灰绿色中厚层中细粒长石砂岩与灰黑色、灰绿色粉砂质 泥岩互层

$22.66 \mathrm{~m}$

15. 深灰色粉砂质泥岩和泥岩, 夹中厚层状泥质胶结的粉细 砂岩 $25.57 \mathrm{~m}$

14. 深灰色粉砂质泥岩和泥岩, 夹中厚层状泥质胶结的粉细 砂岩

$55.14 \mathrm{~m}$

13. 灰色、深灰色中厚层泥质胶结的粉细砂岩, 夹灰黑色粉 砂质泥岩

$31.55 \mathrm{~m}$

12. 灰色、灰绿色中厚层泥质胶结细砂岩, 与灰色粉砂质泥 岩和钙质泥岩互层

$89.21 \mathrm{~m}$ 
11. 灰色、灰绿色粉砂质泥岩、钻质泥岩, 夹灰色中厚层泥 质细砂岩透镜体

$72.65 \mathrm{~m}$

10. 灰色、深灰色中厚层细粒石英砂岩, 与深灰色、灰黑色 粉砂泥岩互层, 粉砂泥岩内夹小型灰岩透镜体, 砂岩层 面上具有对称波痕

$118.28 \mathrm{~m}$

9. 灰色、灰黑色粉砂质泥岩和钙质泥岩与薄层板状钙质粉 砂岩互层, 夹中厚层细砂岩透镜体和砂屑泥灰岩透镜体

$79.03 \mathrm{~m}$

8. 灰黑色、深灰色薄中层微晶灰岩, 灰岩具有泥质条带和 纹层理

$2.99 \mathrm{~m}$

7. 灰色、深灰绿色细粒长石石英砂岩、钙质粉砂岩, 与灰 黑色粉砂泥岩、钙质泥岩互层 $50.28 \mathrm{~m}$

6. 灰黑色粉砂质泥岩、钙质泥岩夹钙质粉砂岩透镜体

$48.23 \mathrm{~m}$

5. 灰色、深灰色中厚层钙质胶结细粒长石石英砂岩, 夹灰 黑色粉砂质泥岩和泥质粉砂岩

$51.84 \mathrm{~m}$

4. 深灰色、灰黑色粉砂泥岩、钙质泥岩具有粉砂条带的泥 灰岩, 夹灰色、灰绿色中厚层状钻质胶结中细砂岩, 底 部为红色风化壳层. 与下伏中二叠统地层呈假整合接触 $56.57 \mathrm{~m}$

\section{中二叠统 (哲斯组)}

厚 $148.37 \mathrm{~m}$

3. 深灰色、灰黑色钻质粉砂泥岩和钙质泥岩, 夹钙质粉砂 岩和小型泥灰岩透镜体 $122.69 \mathrm{~m}$

2. 灰色、灰黑色、灰绿色中厚层泥质粉砂岩、钙质泥岩和 钙质细粒砂岩, 局部夹泥灰岩

$19.92 \mathrm{~m}$

1. 灰色、灰绿色厚层中细粒长石石英砂岩(下限不详) $5.76 \mathrm{~m}$

\section{2 组段综述及对比}

林一段：灰色、灰绿色中-厚层中-细粒长石石 英砂岩和薄层泥质粉砂岩及粉砂泥岩为主, 夹灰 色薄-中层砂屑灰岩和厚层含细砾中-粗粒砂岩; 砂岩 层面普遍具大型振荡波痕 (潮坪环境); 含双壳类 Palaeanodonta sp., Palaeomutella sp., Anthraconaia sp. 和植物化石碎片. 底部为红色风化壳层 (另文讨论). 与下伏中二叠统地层呈假整合接触, 厚 $1232.81 \mathrm{~m}$.

该段还见于内蒙古正镶白旗额力图牧场剖面的 额里图组及吉林九台市波泥河子杨家沟剖面的杨家 沟组. 前者主要为紫色、灰紫色、灰褐色中-厚层含 细砾中粗石英砂岩, 上部夹灰紫色含角砾晶屑凝灰 岩, 底部为英安玢岩; 后者主要由深灰色厚层状同生 砾灰岩、角砾灰岩和灰色、灰白色厚层砂砾岩组成, 底界位于深灰色厚层灰岩的底部.

林二段: 黑色、灰黑色页岩、粉砂质页岩和粉砂 质板岩为主, 夹灰绿色中厚层细粒砂岩. 顶部夹灰色、
灰绿色中-厚层安山岩和含角砾凝灰岩. 厚 $1080.52 \mathrm{~m}$.

该段在额力图牧场剖面显示近物源深水沉积, 其下部为灰色、灰绿色凝灰质中细粒岩屑砂岩为主, 夹晶屑凝灰岩、粉砂岩和粉砂质泥岩, 上部为深灰色 粉砂质页岩和泥质页岩夹细砂岩; 在波泥河子杨家 沟剖面却表现远源深水沉积特征, 由单一灰黑色粉 砂质页岩和泥质页岩组成.

林三段：灰色、深灰色、灰褐色薄层板状粉砂 岩和泥质粉砂岩与灰褐色、暗紫色中-厚层状中-粗 粒长石石英砂岩互层, 局部夹灰黑色薄板状粉砂泥 岩、薄层灰岩和灰岩透镜体, 采到大量双壳类 Palaeanodonta sp., Palaeomutela soronensis, P. cf. trigonalis, $P$. hahaiensis, $P$. cf. semilunulata 等和植物 化石碎片 Paracalamites sp., Noeggerathiopsis sp.等. 厚 $1791.72 \mathrm{~m}$.

该段在额力图牧场剖面为灰白色、灰绿色中粗粒 含砾长石砂岩夹粉细砂岩和粉砂质页岩; 在波泥河 子杨家沟剖面为灰色、灰绿色泥质粉砂岩和钙质页岩 为主, 夹薄-中层泥灰岩和灰岩透镜体, 含丰富海相 双壳类化石.

林四段: 深灰色、黑色泥质页岩、碳质页岩、粉 砂质泥岩和泥质粉砂岩为主, 夹灰绿色、灰色薄中层 或透镜层状细粒长石石英砂岩及灰岩透镜体. 泥页 岩中采到大量叶肢介化石 Palaeolimnadia sp., Huanghestheria sp., Pemphicyclus cf. trochoides 等, 双壳类 Palaeanodonta sp., Palaeomutela soronensis, P. cf. trigonali 等, 以及植物化石碎片 Paracalamites sp., Noeggerathiopsis $\mathrm{sp}$. 等. 薄层灰岩中含有丰富苔蘚虫 等典型海相化石(图 3(A)中(a) (d); 图 3(B)中(a)). 厚 $501.07 \mathrm{~m}$. 该段在内蒙古阿鲁科尔沈旗陶海营子剖面, 相当于林一段-林三段的地层没有出露, 林四段沉积 很厚, 近 $2000 \mathrm{~m}$, 岩性主要为灰黑色、黑色粉砂质页 岩和凝灰质粉砂岩夹灰色、灰绿色细粒长石石英砂岩; 在正镶白旗额力图牧场剖面主要为灰黑色粉砂质板 岩和薄板状粉砂岩, 夹灰色、褐灰色中细粒长石石英 砂岩, 厚仅约 $300 \mathrm{~m}$, 厚度明显变小, 粒度变粗.

林五段: 灰绿色、灰白色薄-中-厚层中细粒硬砂 岩、泥质粉砂岩、粉砂质泥岩和灰褐色厚层块状砂屑 灰岩和角砾屑灰岩, 夹粉红色薄层安山岩、凝灰岩. 厚层灰岩中含有大量苔藓虫、海绵骨针等典型海相化 石(图 3(B)中(b) (i)). 厚 $327.52 \mathrm{~m}$. 林五段顶部被燕 山期花岗岩侵人. 


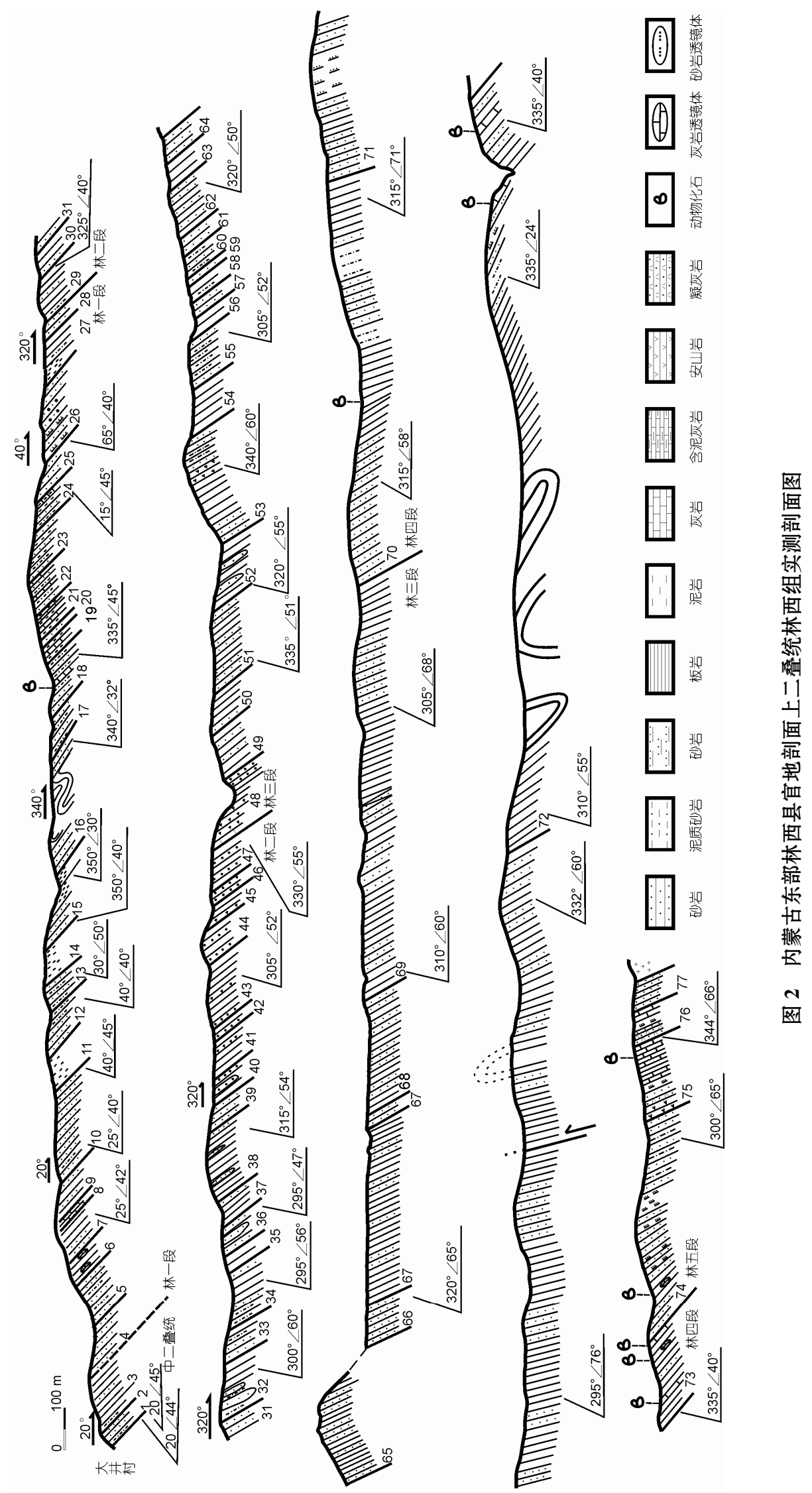


(A)

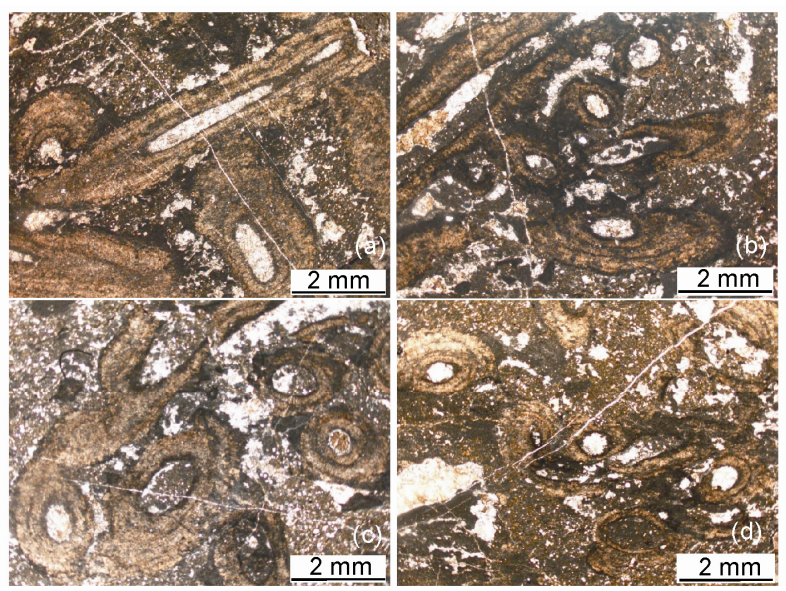

(B) (a)
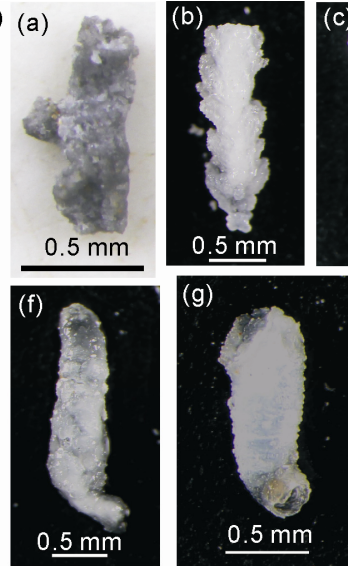
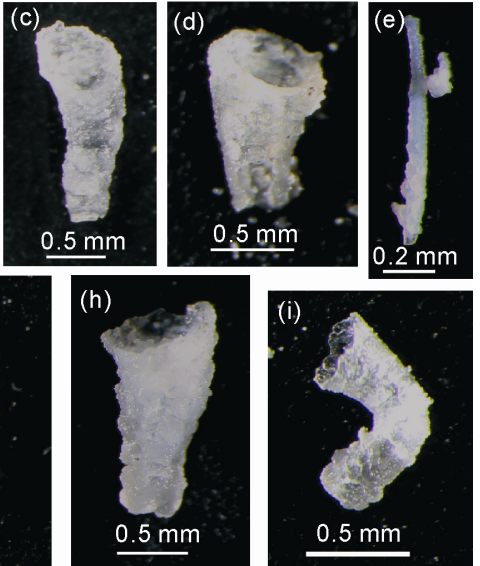

图 3 林西县官地-翟家沟剖面林西组上部林四段 林五段灰岩中苔藓虫和海绵骨针化石

(A)图：(a) (d)为藻黍结苔藓虫格架, 林四段, 内蒙古林西县官地镇半拉山; (B)图: (a)为苔藓虫茎杆-示茎杆分枝, 林四段; (b), (f)为苔藓 虫茎杆-示茎杆分枝, 林五段; (c), (d), (g) ( i) 为苔藓虫虫室-示圆形室口和体表装饰, 林五段; (e)为海绵骨针, 林五段; 内蒙古林西县官 地镇半拉山

该段在内蒙古正镶白旗额力图牧场额里图组上 部(林五段)和吉林九台市波泥河子杨家沟剖面马达 屯组, 均出露以安山岩、安山玢岩、安山角砾岩、凝 灰岩和凝灰角砾岩为主的火山岩, 在杨家沟组黑色 页岩中发现大量小型连体海百合茎化石(图 5(a) (e)); 在内蒙古阿鲁科尔沁旗陶海营子剖面相当于林五段 下部的纹层状薄层沉凝灰岩切片中发现大量苔藓虫 化石(图 4(a) (f)), 上部以灰色、灰褐色薄层粉砂岩和 薄中层长石石英砂岩为主, 夹粉砂质板岩和灰岩透 镜体.

上述 4 个剖面均未见顶界. 依据化石和沉积相序, 上二叠统林西组划分的 5 个岩性段在兴蒙地区可以 概略对比(图 6).

\section{3 讨论}

华北板块、西伯利亚板块和中间地块在兴蒙地区 的最终闭合、兴蒙海槽禇皱隆起的时代是地质界长期 争论的重大地质问题 ${ }^{[5,6]}$. 争论的焦点是对以林西组 为代表的晚二叠世沉积的构造-古地理环境的不同认 识. 目前, 绝大部分学者认为该区上二叠统属陆相沉 积 ${ }^{[7 ~ 19]}$, 中二叠世末期两大板块已经最终闭合, 兴蒙 地区属海西褶皱带. 黄本宏 ${ }^{[8,9]}$ 认为东北地区在晚二 叠世初或早二叠世末, 全区上升隆起, 海水退出, 结 束了该区古生代漫长的海陆变迁史, 晚二叠世全区 广泛发育了陆相沉积. 王鸿祯等人 ${ }^{[10]}$ 通过区域地质 研究得出, 晚二叠世早期北山至兴安和延边的海槽
褶皱隆起，形成一系列内陆盆地，并和准噶尔、华北 盆地连成统一大陆, 东北地区发育典型的陆相活动 类型的沉积产物. 李锦轶 ${ }^{[11]}$ 根据岩性岩相特征, 将 石炭纪至二叠纪构造层分成 3 个岩相带, 并认为上二 叠统均为陆相. 王荃等人 ${ }^{[13]}$ 认为在晚古生代晚期, 随着古洋壳的不断消减, 华夏与安加拉二古陆逐渐 靠近，其间的古洋盆渐趋收缩，至晚二叠世，它们终 于沿蒙古南部的索朗克尔、我国的苏尼特至林西一线 相互碰撞, 整个研究区内的上二叠统均为陆相沉积. 刘永高等人 ${ }^{[14]}$ 从林西组各岩性段展布规律、古地理 环境、生物演化特征、岩相分布特征及古流向资料等, 表明该组形成于以湖盆北西边缘断裂为主要沉陷作 用的半地堑式内陆沉降盆地. 余和中 ${ }^{[16]}$ 认为早二叠 世末-晚二叠世初, 松辽盆地及其周边均上升隆起, 海水退出, 结束了本区古生代以来漫长的海陆变迁 史，而进人陆相沉积时期，大兴安岭 (即黑河至林西) 沉积区发育有一系列边缘前陆盆地磨拉石式和较大 型的湖泊相(早期可能为咸水至半咸水, 后期为淡水) 堆积, 沉积了巨厚的细碎屑岩和富含火山物质的林 西组(陶海营子组). 方德庆等人 ${ }^{[17]}$ 针对松辽盆地周边 二叠系地表出露分散且多呈断片产出的复杂特点, 运用生物化石、岩性特征、地层接触关系综合分析方 法, 建立了地层间的相互层位和对比关系, 认为二叠 系分布较广, 岩相基本稳定, 厚度变化较大, 区内二 叠系下统为偏碱性中酸性火山岩, 中统是海相或海 陆交互相碎屑-碳酸盐岩建造, 上统为陆相碎屑岩建 


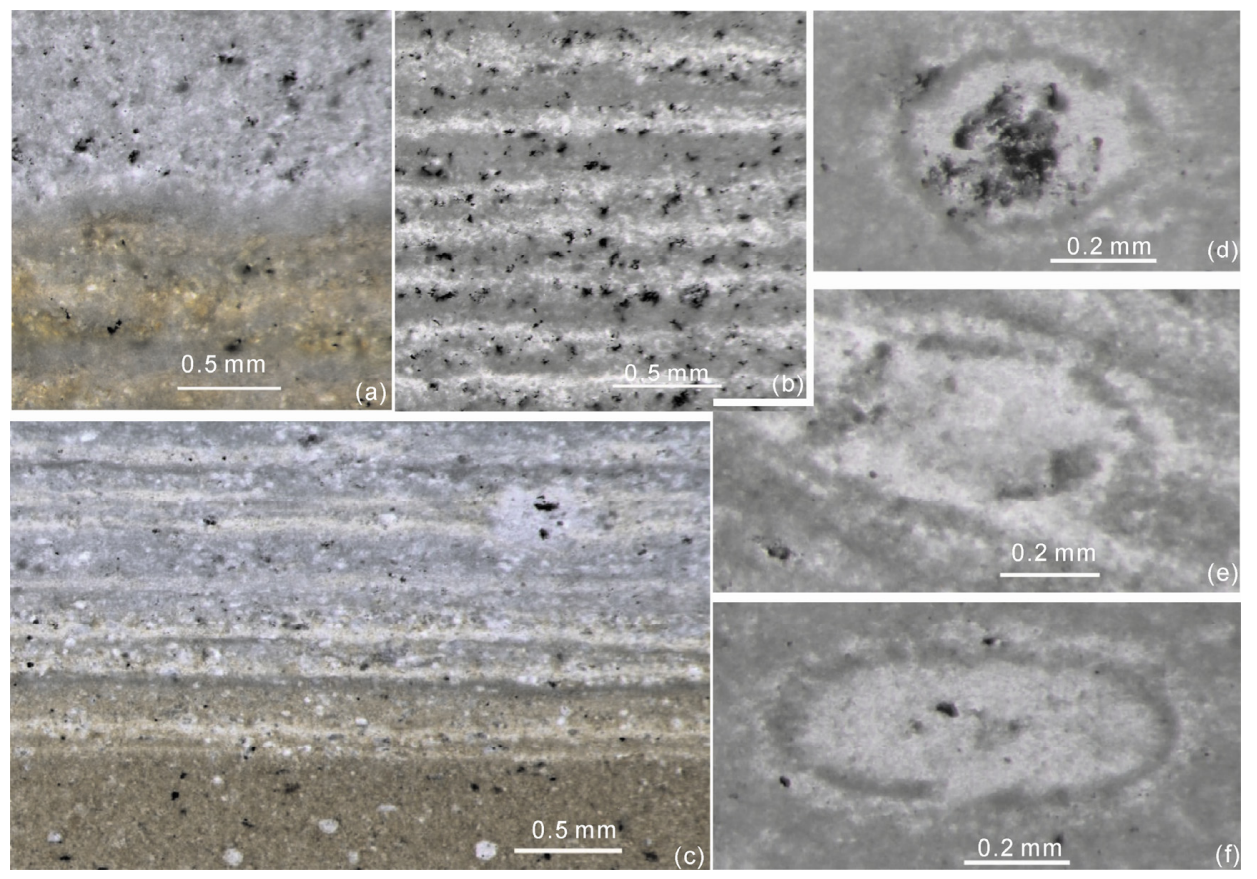

图 4 阿旗陶海营子剖面上部沉凝灰岩切片中的苔蘚虫化石

(a) 岩石薄片: 纹层状凝灰质粉砂岩, 上覆块状硅化凝灰岩, 陶海营子组第 9 层; (b) 岩石薄片: 纹层状硅化凝灰岩, 陶海营子组第 8 层; (c) 岩石薄片: 纹层状泥质粉砂岩渐变为纹层状硅化凝灰岩, 陶海营子组第 8 层; (d) (f) 岩石薄片: 纹层状硅化凝灰岩中的苔藓虫茎杆 切面，可见管壁的孔洞缺口，陶海营子组第 8 层; 内蒙古阿鲁科尔沈旗白音塔拉苏木陶海营子
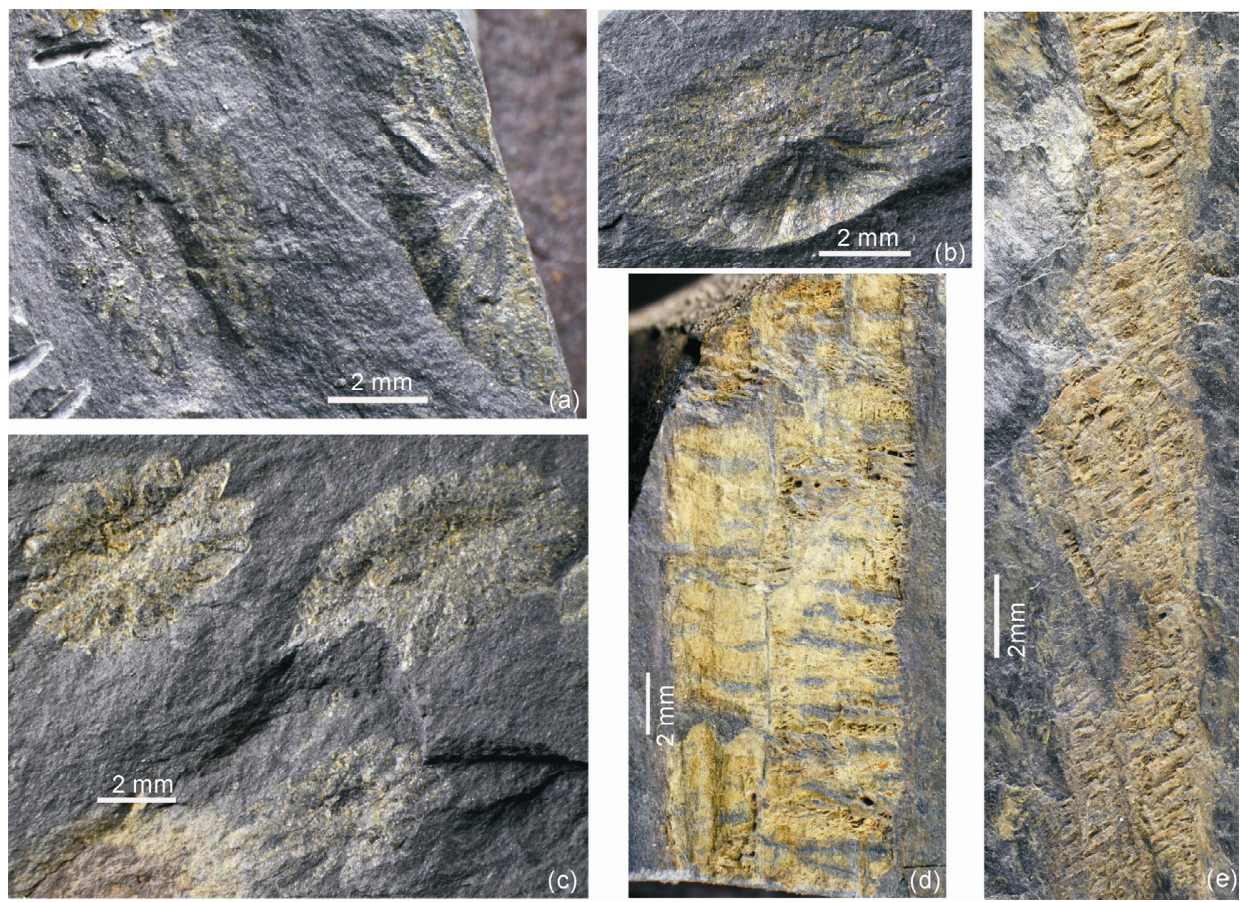

图 5 吉林九台杨家沟剖面杨家沟组暗色泥岩中大量小型连体海百茎化石

(a), (b) 海百合茎口视-轮状茎; (c) 海百合茎口视-星状茎; (d) 海百合柄柱; (e) 海百合腕枝; 杨家沟组中部, 吉林九台县波泥河子杨家沟 

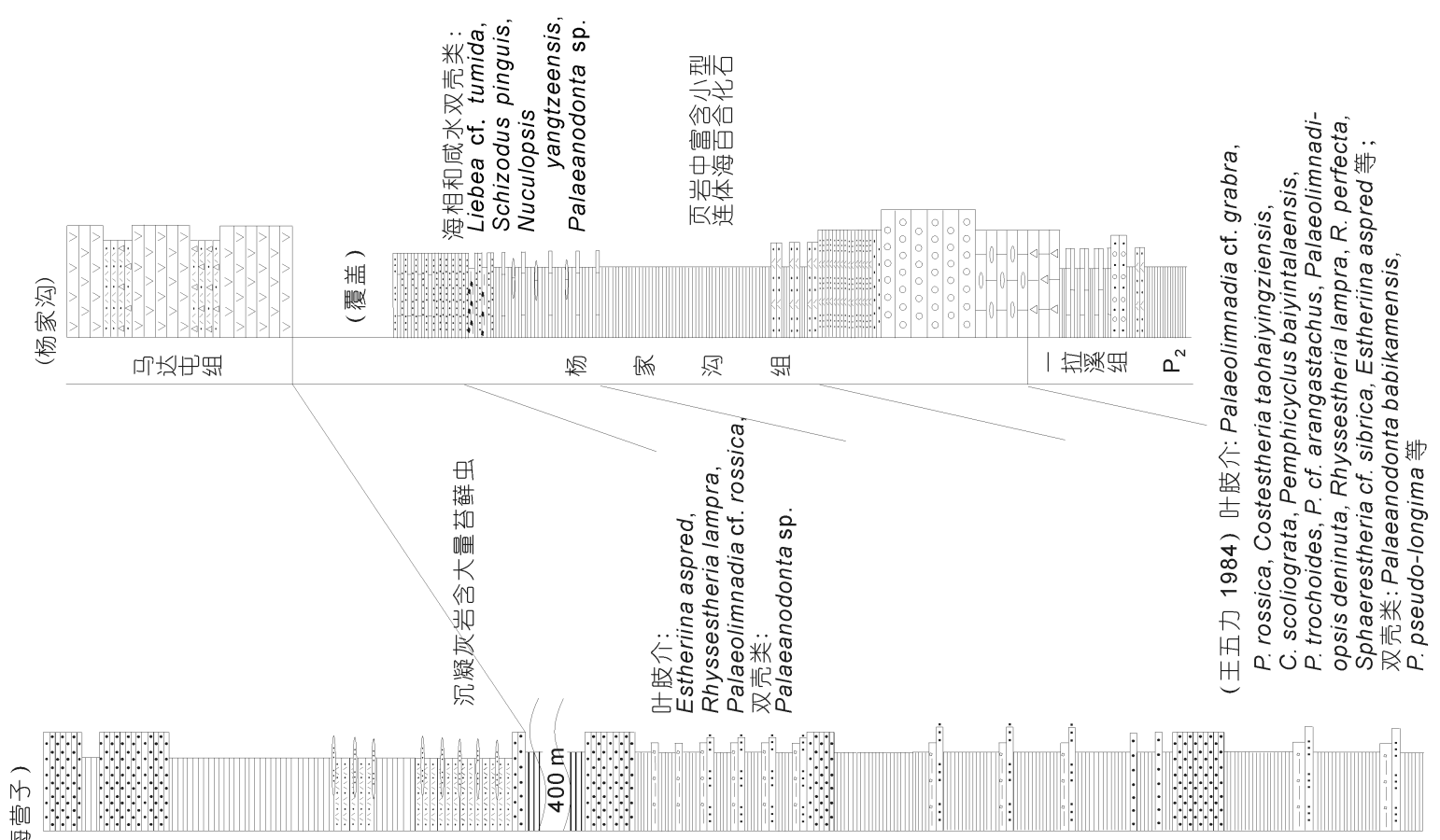

齿

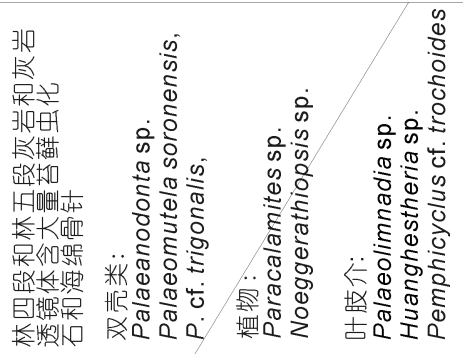

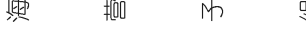

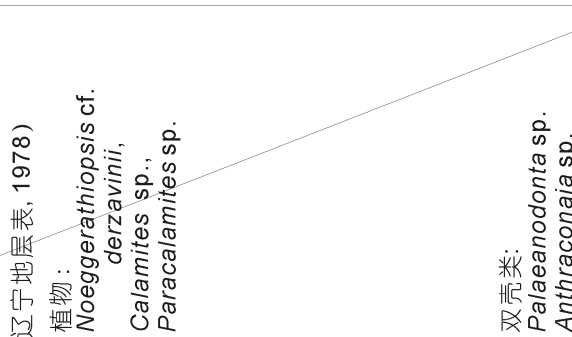

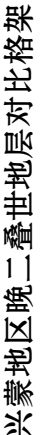
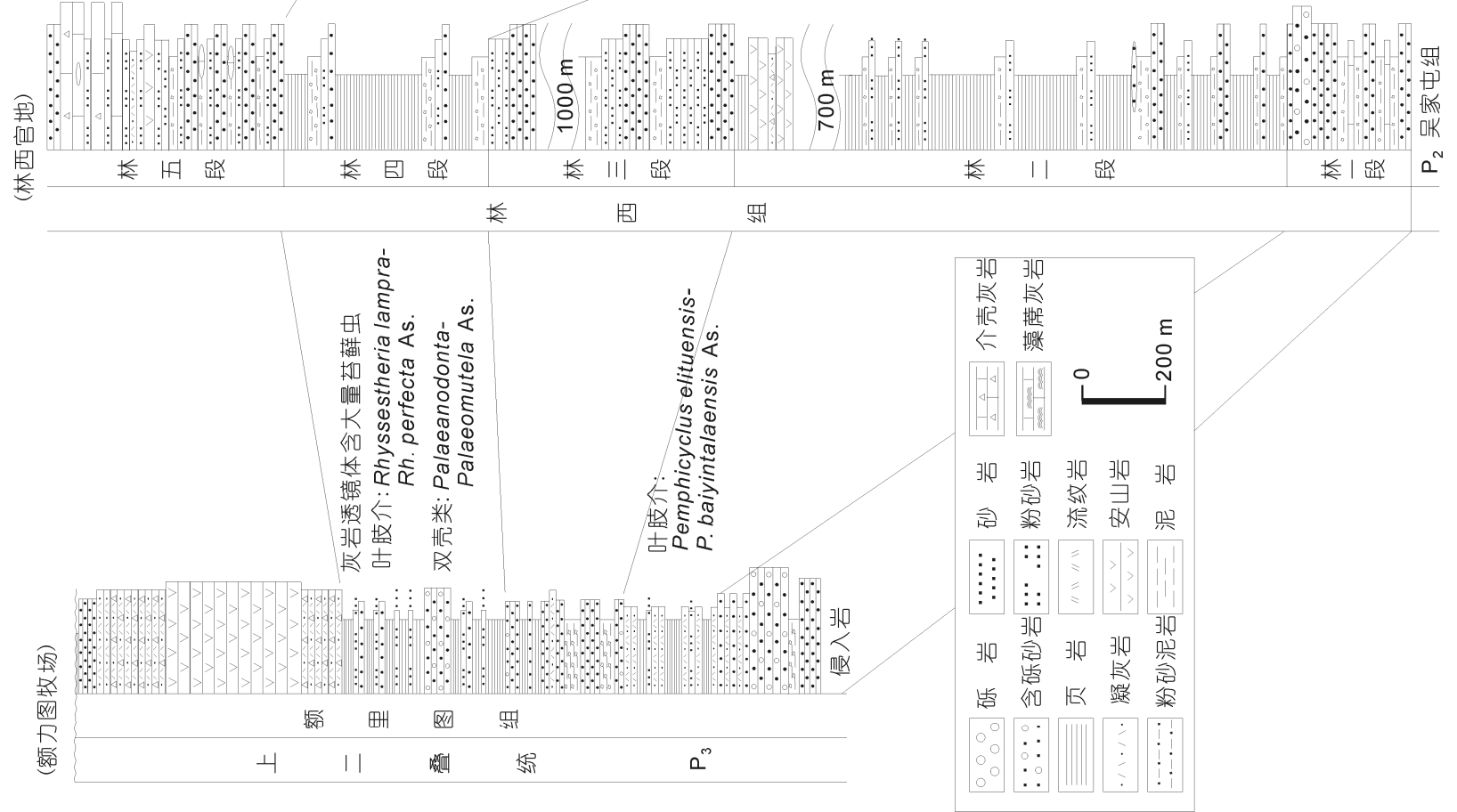
造. 李福来等人 ${ }^{[18]}$ 在前人研究的基础上, 应用地球 化学方法, 对内蒙古东北地区上二叠统林西组的沉 积环境进行了研究, 通过沉积环境判别指标的分析, 确定林西组为开阔的淡水环境, 主要为陆相沉积体 系, 在其沉积初期为海陆交互环境. 张兴洲等人 ${ }^{[19]}$ 认为晚二叠世-早三叠世, 华北板块与佳蒙地块发生 陆-陆碰撞, 残余洋盆消失, 形成陆相沉积盆地. 另 外, 少数学者认为晚二叠世早-中期为封闭内海盆地, 晚期转变成淡水湖盆 ${ }^{[20,21]}$, 印支构造期兴蒙地区禇 皱隆起.

就整个东北亚地区二叠纪地层的研究现状来看, 海相化石和海相沉积在中国东北、蒙古、日本东北和 俄罗斯远东等地区的乌拉尔统、瓜德鲁普统至乐平统 下部吴家坪阶均有广泛分布 ${ }^{[22 ~ 29]}$. 但在乐平统上部 长兴阶，除在本属古海洋环境的日本东北和俄罗斯 远东地区见有腕足类、蜓类和牙形石等海相化石组合 外 ${ }^{[30,31]}$, 在蒙古和中国东北并未见确切的海相化石 和海相沉积报道 ${ }^{[25,32]}$. Manankov 等人 ${ }^{[25]}$ 总结了蒙古 中部-东北部海盆区和蒙古东南部海盆区 2 个主要二 叠系海相沉积区带海相层系的空间分布、地层划分和 生物地层区划方案, 标出的海相化石组合仅限于上 二叠统下部吴家坪阶层位以下, 在上二叠统上部长

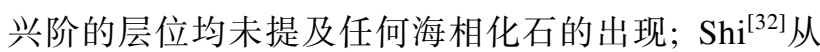
生物地层学、古生物学及古地理指示含义等方面对东 亚和东北亚地区的海相二叠系进行了论述和总结, 在其编制的东亚和东北亚地区二叠纪海相生物地层 格架表中, 俄罗斯远东滨海区二叠系、日本东北二叠 系、以及蒙古和中国东北中-下二叠统均普遍产出腕 足类、头足类、有孔虫、双壳类、牙形石等不同类型 的海相动物化石组合, 但将中国东北和蒙古的晚二 叠世乐平统(林西组)明确标定为非海相沉积, 俄罗斯 远东的贝加尔和维尔霍扬斯克地区在晚二叠世晚期 亦为非海相沉积, 说明在所述的非海相沉积区迄今 并未发现确切的海相化石.

此外, 余和中 ${ }^{[33]}$ 、张永生等人 ${ }^{[34]}$ 对松辽盆地及外 围石炭-二叠系的烃源岩特征进行了探讨. 余和中 ${ }^{[33]}$ 认为松辽盆地石炭-二叠系是烃源岩层系, 在早白严 世晚期开始二次生烃，油气并生，但生气强度超过生 油强度; 张永生等人 ${ }^{\left[{ }^{[3]}\right.}$ 认为松辽盆地及外围的中、上 二叠统发育中等-较好烃源岩, 是该区上古生界 2 套 区域主力生烃层系，具有良好的油气资源远景，可望 构成松辽及外围地区油气勘查战略接替新层系.
由上可知, 以林西组为代表的兴蒙地区晚二叠 世晚期为陆相沉积是目前的主流观点, 并据此提出 西伯利亚板块、华北板块及中间地块拼合、古亚洲洋 闭合的大地构造演化模式 ${ }^{[35 ~ 38]}$. 近年来, 越来越多 的研究证实东北-兴蒙地区上古生界并未发生区域变 质作用 ${ }^{[39 \sim 42]}$, 使得这一长期以来被视为中生代盆地 “变质基底”的上古生界构造层的油气、页岩气等资源 潜力和前景日益受到业界的高度关注. 就上二叠统 而言, 总体是以陆相沉积模式指导油气及其他矿产 资源调查评价和研究的.

\section{4 结论}

本次研究在内蒙古东部林西县官地剖面上二叠 统林西组上部林四段至林五段厚层灰岩和灰岩透镜 体中首次发现大量苔藓虫和海绵骨针化石(图 3(A)中 (a) (d); 图 3(B)中(a) (i)). 此外，在阿鲁科尔沁旗陶 海营子剖面陶海营子组上部的沉凝灰岩切片中也发 现大量苔藓虫化石(图 4(a) (f)). 在吉林九台剖面杨 家沟组暗色页岩中发现大量小型连体海百合茎化石 (图 5(a) (e)). 从生态特征来看, 现代苔藓虫大多数 为海生, 在热带、温带到极区的海洋中均能生存, 仅 一个很小的类群(护唇纲)生活在淡水里, 但淡水型苔 藓虫无坚固的外壳, 不能保存为化石 ${ }^{[43]}$. 苔藓虫适 应性很强, 从滨海潮坪到 $5500 \mathrm{~m}$ 的深海都有分布, 一般在 25 60 $\mathrm{m}$ 的水深最多, 营底栖固着或附生在其 他物体上; 海绵被认为是最原始最低等的海生多细 胞动物，其体壁内多具有支持的针状骨骼，称骨针， 由胶原蛋白、碳酸钙和二氧化硅组成，海绵骨针可在 古代地层中作为化石保存下来; 海百合是一种始见 于石炭纪的棘皮动物, 生活于海里, 由于长得像植物, 故称之为海百合, 现生种的海百合不论浅海或深海、 热带珊瑚礁或高纬度海域, 都能发现其踪迹. 可见, 本区上二叠统上部采集到的苔藓虫、海绵骨针和海百 合茎均为典型的海相化石. 除苔藓虫和海绵之外, 这 些灰岩层中亦有可能存在其他属种的海相化石. 因 此，对在林西组上部发现的多层灰岩及其海相化石 尚需作进一步深人研究.

林西组上部灰岩中典型海相化石的发现，首次 揭示兴蒙地区在晚二叠世晚期仍属海相或以海相为 主的沉积环境, 对厘定兴蒙海盆的最终闭合提供了 新的证据, 并将促进东北-兴蒙地区晚二叠世新层系 油气、页岩气(油)以及其他矿产勘查研究思路的调整. 
中国地质大学(北京)研究生刘思宇、侯鹏飞、刘钊、苏文强和北京科技大学研究生于鹏等参加部分野外工作, 在 此一并致谢!

\section{参考文献}

1 顾国寅, 胡泽瑾. 林西组地层特征及时代. 内蒙古区域地质, 1982, 10: 28-34

2 梁仲发. 东北北部及内蒙古东部晚二叠世的一些双壳类化石及几个有关地层问题. 沈阳地质矿产研究所所刊, 1982, 4: 130-148

3 内蒙古自治区地质矿产局. 内蒙古自治区区域地质志. 北京：地质出版社, 1991. 197-198

4 张永生, 牛绍武, 田树刚, 等. 内蒙古林西地区上二叠统林西组叶肢介化石的发现及意义. 地质通报, 2012, 31: 1394-1403

5 何国琦, 郡济安. 内蒙古东南部(昭盟)西拉沐伦一带早古生代蛇绿岩建造的确认及其大地构造意义. 见: 地质矿产部沈阳地质矿产 研究所. 中国北方板块构造论文集, 第 1 集. 北京: 地质出版社, 1983.243-250

6 王成文, 金巍, 张兴洲, 等. 东北及邻区晚古生代大地构造属性新认识. 地层学杂志, 2008, 32: 119-136

7 辽宁省区域地层表编写组. 东北地区区域地层表, 辽宁省分册. 北京: 地质出版社, 1978

8 黄本宏. 东北北部石炭二叠纪陆相地层及古地理概况. 地质论评, 1982, 28: 395-401

9 黄本宏. 大兴安岭地区石炭-二叠系及植物群. 北京: 地质出版社, 1993

10 王鸿祯. 中国古地理图集. 北京: 地图出版社, 1985. 47-51

11 李锦轶. 内蒙古东部中朝板块与西伯利亚板块之间古缝合带的初步研究. 科学通报, 1986, 31: 1093-1096

12 吉林省地质矿产局. 吉林省区域地质志. 北京：地质出版社, 1988. 1-734

13 王荃, 刘雪亚, 李锦轶. 中国内蒙古中部的古板块构造. 中国地质科学院院报, 1991, 22: 1-15

14 刘永高, 谭佐山, 刘书金. 内蒙古东部的上二叠统林西组. 内蒙古地质, 1999, 2: 21-26

15 《中国地层典》编委会. 中国地层典-二叠系. 北京: 地质出版社, 2000.75

16 余和中. 松辽盆地及周边地区石炭纪-二叠纪岩相古地理. 沉积与特提斯地质, 2001, 21: 70-83

17 方德庆, 庞庆山, 赵利华, 等. 松辽盆地周边二叠系讨论. 大庆石油学院学报, 2004, 28: 96-98

18 李福来, 曲希玉, 刘立, 等. 内蒙古东北部上二叠统林西组沉积环境. 沉积学报, 2009, 27: 265-272

19 张兴洲, 乔德武, 迟效国, 等. 东北地区晚古生代构造演化及其石油地质意义. 地质通报, 2011, 30: 205-213

20 任纪舜. 印支运动及其在中国大地构造演化中的意义. 中国地质科学院院报, 1984, 9: 31-34

21 和政军, 刘淑文, 任纪舜, 等. 内蒙古林西地区晚二叠世-早三叠世沉积演化及构造背景. 中国区域地质, 1997, 16: 403-409

22 Kotlyar G V, Nikitina A P, Zhuravlev A V, et al. Midian (upper Wordian-Capitanian) mixed faunas of Southeastern Asia (in Russian). Byulleten Moskovskogo Obshches, 2003, 78: 33-48

23 Ehiro M, Misaki A. Stratigraphic range of the genus Monodiexodina (Permian Fusulinoidea): Additional data from the Southern Kitakami Massif, Northeast Japan. J Asian Earth Sci, 2004, 23: 483-490

24 Ehiro M, Misaki A. Middle Permian ammonoids from the Kamiyasse-Imo district in the Southern Kitakami Massif, Northeast Japan. Paleontol Res, 2005, 9: 1-14

25 Manankov I N, Shi G R, Shen S Z. An overview of Permian marine stratigraphy and biostratigraphy of Mongolia. J Asian Earth Sci, 2006, 26: 294-303

26 Ehiro M. A new species of Stacheoceras (Permian ammonoid) from the Upper Permian in the South Kitakami Belt, Northeast Japan. Paleontol Res, 2006, 10: 261-264

27 Chen Z Q, Shi G R. Isogramma Meek and Worthen, 1870 (Dictyonellida, Brachiopoda) from the upper Palaeozoic of East Asia: Implications for biogeography and evolutionary trends. J Asian Earth Sci, 2006, 26: 405-423

28 田树刚, 张永生, 王俊涛, 等. 兴安-内蒙古地区晚古生代生物礁及其构造和油气意义. 中国科学：地球科学, 2011, 41: 493-503

29 王俊涛, 张永生, 宋天锐, 等. 内蒙古扎秉特旗中二叠统岩石地层、生物地层特征及沉积环境分析. 地层学杂志, 2011, 35: 375-384

30 Ganelin V G, Biakov A S, Karavaeva N I. Some theoretical problems in the stratigraphy and stratigraphic scale of the Permian in northeastern Asia. In: Gladenkov Yu B, Kuznetsova K I, eds. Toward Detailed Stratigraphic Schemes and Paleogeographic Reconstructions (in Russian). Moskow: Geos, 2001. 194-208

31 Takahashi S, Yamakita S, Suzuki N, et al. High organic carbon content and a decrease in radiolarians at the end of the Permian in a newly discovered continuous pelagic section: A coincidence? Palaeogeogr Palaeoclimatol Palaeoecol, 2009, 271: 1-12

32 Shi G R. The marine Permian of East and Northeast Asia: An overview of biostratigraphy, alaeobiogeography and palaeogeographical implications. J Asian Earth Sci, 2006, 26: 175-206

33 余和中, 蔡希源, 韩守华, 等. 松辽盆地石炭-二叠系烃源岩研究. 沉积与特提斯地质, 2003, 23: 62-66

34 张永生, 王延斌, 卢振权, 等. 松辽盆地及外围地区石炭系-二叠系烃源岩的特征. 地质通报, 2010, 30: 214-220 
35 陈琦, 邹新民, 仇甘霖, 等. 内蒙造山带南部古板块构造演化. 地质论评, 1993, 39: 477-483

36 Xiao W J, Windley B F, Hao J, et al. Accretion leading to collision and the Permian Solonker suture, Inner Mongolia, China: Termination of the central Asian orogenic belt. Tectonics, 2003, 22: 8-1-8-20

37 李朋武, 高锐, 管烨, 等. 内蒙古中部索伦林西缝合带封闭时代的古地磁分析. 吉林大学学报(地球科学版), 2006, 36: 744-758

38 聂凤军, 江思宏, 张义, 等. 中蒙边境中东段金属矿床成矿规律和找矿方向. 北京: 地质出版社, 2007. 469-475

39 张兴洲, 周建波, 迟效国, 等. 东北地区晚古生代构造-沉积特征与油气资源. 吉林大学学报(地球科学版), 2008, 38: 719-725

40 张兴洲, 马玉霞, 迟效国, 等. 东北及内蒙古东部地区显生宙构造演化的有关问题. 吉林大学学报(地球科学版), 2012, 42: 1269-1285

41 周建波, 张兴洲, 马志红, 等. 中国东北地区的构造格局与盆地演化. 石油与天然气地质, 2009, 30: 530-538

42 施璐, 郑常青, 张兴洲, 等. 内蒙古林西地区二叠系林西组泥质岩石动力变质. 世界地质, 2012, 31: 51-57

43 杨敬之, 陆麟黄. 苔藓虫化石. 北京: 科学出版社, 1965 